\title{
Faktor yang Mempengaruhi Keputusan Petani Terhadap Hasil Panen Lada Putih di Kecamatan Simpang Teritip Kabupaten Bangka Barat
}

D O I: $10.18196 /$ agr.2127

\begin{abstract}
This research aims to determine the factors that influence farmers' decisions to harvest white pepper crops, which related to delay selling or direct selling. Method of research used in this research was survey method, stratified random sampling was used on 60 respondents which categorized as large farmers and small farmers, and the method of analysis used logistic binary regression. The result showed that there was a difference between the large farmers and small farmers' decisions. The tendency for large farmers do delay the selling and the tendency of small farmers as much as 57 percent do direct selling and 43 percent of farmers do delay selling. There are three variables that influence farmers' decisions, namely the amount of produc-
\end{abstract}

tion, price perception and consumption needs.

Keywords: farmers' decisions, white pepper, binary logistic regression.

\section{INTISARI}

Penelitian ini bertujuan untuk menentukan faktor-faktor yang mempengaruhi keputusan petani terhadap hasil panen lada putih, yang terkait dengan menunda penjualan atau langsung menjual. Metode penelitian yang digunakan adalah metode survey, stratified random sampling digunakan untuk memilih 60 responden yang dikategorikan sebagai petani besar dan petani kecil, dan metode analisis yang digunakan regresi biner logistik. Hasil penelitian menunjukkan terdapat perbedaan keputusan terhadap hasil panen antara petani besar dan petani kecil. Kecenderungan petani besar menunda penjualan, sedangkan kecenderungan petani kecil sebanyak 56,7 persen langsung menjual hasil panen dan 43,3 persen responden tunda jual hasil panen. Faktor yang mempengaruhi keputusan petani lada putih terhadap hasil panen yaitu variabel jumlah produksi persepsi harga, dan kebutuhan konsumsi.

Kata kunci: keputusan petani, lada putih, regresi biner logistik.

\section{PENDAHULUAN}

Lada putih yang berasal dari Provinsi Bangka Belitung sudah dikenal di pasar dunia (internasional) dengan brand 'Muntok White Pepper". Usahatani lada putih ini, didukung oleh keadaan geografis pulau Bangka dan Belitung yang cocok dan memiliki keunggulan tersendiri dari sisi produk yang dihasilkan. Hal tersebut dapat dilihat dari produk (lada putih) yang dihasilkan petani memiliki ciri khas tersendiri dengan lada putih yang lain yaitu aroma wangi dan citra rasa yang pedas. Berdasarkan geograsif tersebut, Kementerian Kehakiman dan Hak Azasi Manusia (Kemenhum dan Ham) pada tahun 2010 mengeluarkan Indikasi Geografis (IG) yang merupakan kekayaan intelektual yang dimiliki Provinsi Bangka Belitung ini (Badan 
Pengelolaan, Pengembangan dan Pemasaran Lada Putih, 2010).

Lada Putih dihasilkan dari enam kabupaten di Provinsi Bangka Belitung, yaitu Bangka, Bangka Barat, Bangka Tengah, Bangka Selatan, Belitung dan Belitung Timur dengan total produksi pada tahun 2013 sebesar 33.596 ton, yang diusahakan oleh 54.099 rumah tangga petani (Dinas Pertanian, Perkebunan dan Peternakan Prov Bangka Belitung, 2014). Kontribusi lada putih ini bagi perekonomian Bangka Belitung dapat dilihat dari nilai ekspor lada putih pada tahun 2014 sebesar US\$ $96.070,22$ meningkat dari tahun sebelumnya yaitu sebesar US\$ 80.847,66 (BP3L, 2015).

Kabupaten Bangka Barat merupakan salah satu kabupaten yang berkontribusi terhadap produksi lada putih di Provinsi Bangka Belitung, dengan sentra produksi di Kcematan Simpang Teritip. Total produksi yang dihasilkan sebesar 36 persen dari total produksi kabupaten sebesar 3.160 ton pada tahun 2014 (Dinas Pertanian, Perkebunan dan Peternakan Kabupaten Bangka Barat, 2015). Lada putih adalah komoditi unggulan dari Provinsi Kepulauan Bangka Belitung yang telah diusahakan masyarakat sejak abad ke-18 Masehi (Oktaviandi, 2009). Kegiatan usahatani lada putih sudah menjadi turun temurun dilakukan oleh masyarakat dan menjadi sumber pendapatan utama petani.

Pendapatan petani lada putih diperoleh dari hasil produksi (produk) yang dijualkan ke pasaran melalui lembaga-lembaga pemasaran yang ada di desa. Hal ini senada dengan penelitian Mawarnita (2013) mengatakan bahwa lada putih yang dihasilkan petani dijual kepada pedagang desa yang bertindak sebagai pedagang pengumpul kecil dan pengumpul besar. Petani dalam memasarkan hasil lada putih memiliki pertimbangan dalam memutuskan untuk menjual langsung atau tunda jual setelah panen. Keputusan petani dipengaruhi oleh sejumlah faktor yaitu kebutuhan hidup sehari-hari, biaya pendidikan sekolah, modal usahatani, harga komoditi, tabungan, sumber pendapatan lain. Faktor-faktor tersebut berkaitan erat dengan penguasaan lahan oleh petani.

Menurut Mubyarto (1973) petani yang dikatakan kaya (petani dengan penguasaan lahan luas) dapat menyimpan hasil panen untuk kemudian dijual sedikit demi sedikit pada waktu yang diperlukan; sedangkan petani yang dikatakan gurem (petani dengan penguasaan sempit) masih kesulitan untuk menyimpan hasil panennya. Oleh karena itu, penelitian ini bertujuan untuk mengetahui faktor apa saja yang mempengaruhi keputusan petaniuntuk langsung menjual atau tunda jual terhadap hasil panen lada putih.

\section{METODE PENELITIAN}

Survey dilakukan di tiga desa di Kecamatan Teritip, Bangka Barat, yaitu Desa Kundi, Bukit Terak dan Air Menduyung. Ketiga desa tersebut dipilih sebagai lokasi penelitian dengan pertimbangan ketiga desa tersebut merupakan sentra penghasil lada putih terbesar di Kecamatan Simpang Teritip. Sampel petani dipilih dengan menggunakan teknik stratified random sampling; dengan strata didasarkan pada skala usahatani (penguasaan lahan) yang dimiliki petani, yakni petani yang mempunyai skala usahatani besar dan petani yang mempunyai skala usahatani kecil. Dari jumlah petani lada putih sebanyak 300 petani, diambil sampel sebanyak 20 persen atau 60 orang; yaitu 20 petani dari setiap desa, masing-masing 10 petani dari kelompok berskala usahatani besar dan berskala usahatani kecil.

Data primer diperoleh melalui pengamatan dan wawancara secara langsung dengan 60 petani responden melalui panduan kuisioner; sedangkan data sekunder untuk memberikan gambaran di lapangan atau merupakan data pendukung informasi yang diterima. Data dan informasi yang telah diperoleh di lapangan dianalisis secara secara deskriptif, dijelaskan dengan bantuan tabel, grafik atau diagram. Faktor-faktor apa saja yang mempengaruhi petani menjual dan menyimpan hasil panen lada putih dianaliisis menggunakan analisis regresi binary logistik dengan persamaan (Pyndick dan Rubinfield, 1981 dalam Hendayana, 2012) sebagai berikut.

$\operatorname{logit}\left(\varlimsup_{j}\right)=\ln \frac{\pi j}{1-\pi j}=\hat{a}_{0}+\hat{a}_{1} \mathrm{x}_{j 1}+\hat{a}_{2} \mathrm{x}_{j 2}+\ldots .+\hat{a}_{\mathrm{n}} \mathrm{x}_{\mathrm{jn}}$

Keterangan :

$\mathrm{Y}=$ Keputusan petani terhadap hasil panen

1 = Langsung menjual hasil panen

$0=$ Tunda Jual

$\mathrm{X}_{1} \quad=$ umur petani (tahun)

$\mathrm{X}_{2}=$ tingkat pendidikan (tahun)

$\mathrm{X}_{3}=$ jumlah anggota keluarga (orang)

$\mathrm{X}_{4}=$ pengalaman usahatani (tahun)

$\mathrm{X}_{5}=$ jumlah produksi lada putih $(\mathrm{kg})$

$\mathrm{X}_{6}=$ luas lahan (ha)

$\mathrm{D}_{1}=$ ketersediaan tempat penyimpanan $(1=\mathrm{ada}, 0=$ tidak ada)

$\mathrm{D}_{2}=$ sumber pendapatan lain $(1=$ ada, $0=$ tidak ada $)$

$\mathrm{D}_{3}=$ persepsi harga $(1=$ tinggi, $0=$ rendah $)$ 


$$
\begin{aligned}
& \mathrm{X} 7=\text { kebutuhan konsumsi }(\mathrm{Rp}) \\
& \mathrm{X} 8=\text { kebutuhan investasi }(\mathrm{Rp})
\end{aligned}
$$

Pendugaan parameter dalam model regresi logistik dilakukan dengan menggunakan metode kemungkinan maksimum (Maximum Likelihood Estimation). Metode kemungkinan maksimum ini digunakan untuk memaksimalkan LF guna mendapatkan nilai parameter $\hat{a}_{\text {t }}$ sedemikian rupa, sehingga probabilitas untuk mendapatkan nilai Y maksimum. Nilai dugaan $\hat{a}_{i}$ dapat diperoleh dengan membuat turunan pertama fungsi logaritma dari likelihood function, terhadap setiap nilai parameter $\hat{a}_{i}$ yang akan kita ketahui, kemudian menyamakannya dengan nol (Supranto, 2004). Setelah melakukan pendugaan parameter model, selanjutnya adalah melakukan pengujian kesesuaian model yang dibentuk. Ketepatan model akan diuji dengan menggunakan statistik chi-square $\left(\div^{2}\right)$, dengan hipotesis sebagai berikut.

$\mathrm{H}_{0}$ : Tidak ada perbedaan antara model dengan data yang diamati (data empiris)

$\mathrm{H}_{1}$ : $\quad$ Ada perbedaan antara model dengan data yang diamati

Sedangkan untuk menguji apakah masing-masing koefisien regresi logistik signifikan, digunakan statistik uji Wald, dengan hipotesis berikut ini.

$\mathrm{H}_{0}: \hat{\mathrm{a}}_{\mathrm{i}}=0$ (variabel umur, tingkat pendidikan, jumlah anggota keluarga, pengalaman usahatani, jumlah produksi, luas lahan, ketersediaan tempat penyimpanan, sumber pendapatan lain, persepsi harga, kebutuhan konsumsi dan kebutuhan investasi tidak mempunyai pengaruh secara signifikan terhadap variabel perilaku petani terhadap hasil panen lada putih)

$\mathrm{H}_{1}$ : $\hat{\mathrm{a}}_{\mathrm{i}}{ }_{\mathrm{i}}$ ' $\mathrm{O}$ (variabel umur, tingkat pendidikan, jumlah anggota keluarga, pengalaman usahatani, jumlah produksi, luas lahan, ketersediaan tempat penyimpanan, sumber pendapatan lain, persepsi harga, kebutuhan konsumsi dan kebutuhan investasi mempunyai pengaruh secara signifikan terhadap variabel perilaku petani terhadap hasil panen lada putih).

Setiap koefisien dalam model regresi logistik $\left(\hat{a}_{i}\right)$ mengukur perubahan dalam perkiraan logit. Jika variabel bebas tertentu $\left(\mathrm{X}_{\mathrm{i}}\right)$ naik 1 unit, sedangkan variabel bebas lainnya tetap, maka secara rata-rata perkiraan logit akan naik atau turun sebesar nilai koefisien tersebut. Interpretasi hasil regresi logistik dapat dilakukan dengan melihat nilai rasio oddsnya. Jika suatu peubah penjelas mempunyai tanda koefisien positif, maka nilai rasio oddsnya akan lebih besar dari satu, atau sebaliknya sebaliknya. Interpretasi terhadap nilai odds ini diperoleh dengan mengambil antilog dari berbagai koefisien. Interpretasi dari nilai odds rasio ini adalah kecenderungan atau peluang $\mathrm{Y}=1$ pada kondisi $\mathrm{x}=1$ sebesar $\exp (\hat{a})$ kali dibandingkan dengan $\mathrm{x}=0$.

\section{HASIL DAN PEMBAHASAN}

Sikap Petani Terhadap Hasil Panen Lada Putih

Sikap petani yang dimaksud yaitu perilaku petani akan bagaimana setelah petani panen. Perilaku petani lada putih ini adalah perilaku petani melakukan tunda jual setelah panen dan perilaku petani langsung menjual atau memasarkan hasil setelah panennya. Petani yang melakukan tunda jual merupakan petani yang setelah panen ada kisaran waktu (jeda) petani menunda jual hasil panennya yaitu di atas tiga bulan atau lebih, sedangkan petani yang langsung jual hasil panen merupakan petani yang setelah panen langsung menjual lada putihnya. Dari total responden tiga desa sejumlah 60 responden, terdapat perbedaan kecenderungan perilaku antara petani dengan lahan luas dan lahan sempit (Tabel 1).

Berdasarkan Tabel 1, responden atau petani terhadap hasil panen ini berbeda-beda antara perilaku petani besar

TABEL I. KELOMPOK PETANI TERHADAP HASIL PANEN LADA PUTIH DI KECAMATAN SIMPANG TERITIP TAHUN 2015

\begin{tabular}{llllll}
\hline No & Keterangan & $\begin{array}{l}\text { Petani besar } \\
\text { Jumlah (orang) }\end{array}$ & $\%$ & $\begin{array}{l}\text { Petani kecil } \\
\text { Jumlah (orang) }\end{array}$ & $\%$ \\
\hline 1 & Langsung jual & 1 & 3,3 & 17 & 56,7 \\
2 & Tunda jual & 29 & 96,7 & 13 & 43,3 \\
& Jumlah & 30 & 100 & 30 & 100 \\
\hline
\end{tabular}


dan perilaku petani kecil dimana dari 30 sampel perilaku petani besar pada saat setelah panen 96,7 persen mereka melakukan tunda jual hasil panennya atau berjumlah 29 orang dan perilaku petani langsung jual sebanyak 3,3 persen atau hanya 1 orang yang langsung menjual hasil panennya. Sementara perilaku petani kecil dari 30 sampel pada saat setelah panen 43,3 persen atau 13 orang yang melakukan tunda jual, dan perilaku petani langsung menjual saat setelah panen yaitu 56,7 persen atau sebanyak 17 orang.

Berdasarkan data primer dari 30 responden petani besar terdapat 1 orang petani yang termasuk dalam kategori petani besar yang langsung menjual hasil panennya. Berdasarkan hasil wawancara dengan petani tersebut alasan yang mempengaruhi petani langsung menjual hasil panennya dengan persentase 3,3 persen yaitu dipengaruhi oleh: i) kebutuhan investasi dimana hasil penjualan lada putih dibelikan emas untuk investasi, ii) persepsi harga tinggi dikarenakan petani melihat pada saat ini harga lada putih mencapai $\mathrm{Rp}$ $170.000 / \mathrm{kg}$ petani ingin membeli kendaraan roda dua, serta iii) kebutuhan konsumsi dimana petani menambah uang belanja isterinya untuk konsumsi atau kebutuhan lain-lainnya untuk anaknya. Selanjutnya alasan petani besar yang melakukan tunda jual hasil panenya dapat dilihat pada Tabel 2.

\section{TABEL 2. ALASAN PETANI BESAR YANG MELAKUKAN TUNDA JUAL HASIL PANENNYA}

\begin{tabular}{llll}
\hline No & Alasan petani & Jumlah & Persentase \\
\hline 1 & Kebutuhan investasi & 29 & 96,7 \\
2 & Adanya Sumber pendapatan lain & 29 & 96,7 \\
3 & Jumlah produksi lada putih & 29 & 96,7 \\
4 & Tradisi & 29 & 96,7 \\
\hline
\end{tabular}

Berdasarkan Tabel 2, kebutuhan investasi yang dimaksud yaitu petani tersebut berinvestasi dalam bentuk menyimpan lada putih, dimana petani bisa menjual lada putihnya kapan saja sesuai dengan keperluan yang nanti akan dihadapinya seperti: untuk modal tanam selanjutnya, kebutuhan mendesak, dan lain-lainnya. Selanjutnya adanya sumber pendapatan lain petani yaitu karet atau sawit, yang digunakan untuk memenuhi kebutuhan hidup petani sehari-harinya dan keluarganya maka petani setelah panen melakukan tunda jual lada putihnya. Jumlah produksi yang dihasilkan petani tinggi atau banyak sehingga petani lebih memilih untuk menunda jual lada putihnya tanpa ada batas waktunya biasanya sampai bertahun-tahun petani menyimpan lada putihnya, dan akan dijual petani pada saat petani benarbenar sedang membutuhkan uang. Selain ketiga alasan tadi, terdapat alasan laian yaitu telah menjadi tradisi masyarakat atau ciri khas dari petani menyimpan hasil panennya karena mereka sangat senang jika pulang ke rumah langsung tercium akan aroma khas dari lada putih.

Berdasarkan data primer dari 30 responden petani kecil akan dibahas alasan yang mempengaruhi petani langsung jual dan tunda jual hasil panen pada Tabel 3.

Berdasarkan Tabel 3, persepsi harga tinggi karena harga lada putih pada saat penelitian mencapai $\mathrm{Rp}$ $170.000 / \mathrm{kg}$, maka petani tidak ingin lama-lama menyimpan hasil panennya, melainkan setelah panen petani langsung menjual lada putihnya, selanjutnya kebutuhan konsumsi petani ini seperti kebutuhan hidup sehari-hari petani yang harus dipenuhi, dikarenakan sumber pendapatan lain dari karetnya tidak banyak. Sedangkan alasan petani kecil untuk melakukan tunda jual yaitu petani mempunyai sumber pendapatan lain seperti karet dan sawit dan kebutuhan investasi dengan persentase 43,3 persen. Adanya sumber pendapatan lain petani seperti karet dan sawit. Semua petani mempunyai sumber pendapatan lain dari usahatani karet sedangkan dari usahatani kelapa sawit hanya 2 petani responden saja yang mengusahakannya. Pendapatan yang didapat petani dari usahatani karet dan kelapa sawit ini sudah cukup untuk memenuhi kebutuhan hidup petani dan keluarganya. Selanjutnya alasan petani melakukan tunda jual untuk kebutuhan investasi atau petani menabung dalam bentuk lada putih dan akan dijual jika petani mempunyai kebutuhan mendesak.

Faktor-Faktor yang Mempengaruhi Keputusan Petani

Berdasarkan persamaan di atas terdapat sebelas variabel yang dimasukkan ke dalam program spss, setelah dianalisis menggunakan Regresi Binary Logistic terdapat 3 variabel yang berpengaruh terhadap keputusan petani terhadap hasil panen lada putihnya. Uji Kelayakan Model atau model goodness of fit dilakukan dengan menggunakan prinsip Hosmer and Lameshow (H-L test). Jika nilai uji H-L sama atau kurang dari 5\% berarti ada perbedaan yang signifikan antara model dengan nilai observasinya, dimana kelayakan model tidak baik karena model dianggap tidak bisa memprediksi nilai observasinya. Jika nilai statistik Hosmer and Lemeshow's Goodness of Fit 
TABEL 3. ALASAN PETANI KECIL YANG MELAKUKAN LANGSUNG JUAL HASIL PANENNYA

\begin{tabular}{llllll}
\hline & & \multicolumn{2}{l}{ Petani Kecil } & & \\
\cline { 3 - 6 } No & Alasan Petani & Langsung Jual & $\begin{array}{l}\text { Persentase } \\
(\%)\end{array}$ & Tunda Jual & $\begin{array}{l}\text { Persentase } \\
(\%)\end{array}$ \\
\hline 1 & Persepsi harga tingai & 20 & 66,7 & - & - \\
2 & Kebutuhan Konsumsi & 17 & 56,7 & - & - \\
2 & Sumber Pendapatan Lain & 17 & 56,7 & - & - \\
\hline 2 & Sumber Pendapatan Lain & - & - & 13 & 43,3 \\
3 & Kebutuhan Investasi & - & - & 13 & 43,3 \\
\hline
\end{tabular}

lebih besar dari 5 persen berarti model mampu untuk memprediksi nilai observasinya dengan kepercayaan 95 persen.

Nilai signifikansi berdasarkan uji Hosmer and Lameshow (H-L) adalah 97,9 persen ( $>5$ persen), maka model regresi logistik yang disusun layak digunakan atau dipakai untuk analisis selanjutnya.

Uji taraf nyata dalam regresi binary logistik menggunakan Uji likelihood atau Uji G dan Uji Wald atau Uji W. Terlihat bahwa untuk model keputusan petani terhadap hasil panen mempunyai peluang chi-square 41.172 dengan tingkat signifikansi 0,000 atau keputusan petani lada putih terhadap hasil panen mempunyai signifikansi pada tingkat 5 persen. Ini menunjukkan bahwa model yang disusun mempunyai hubungan yang signifikan antara variabel bebas dengan variabel tidak bebasnya atau bahwa faktor umur petani, tingkat pendidikan, jumlah anggota keluarga, pengalaman usahatani, luas lahan, jumlah produksi, sumber pendapatan lain, ketersediaan tempat penyimpanan, persepsi harga, kebutuhan konsumsi dan kebutuhan investasi secara bersama-sama berpengaruh terhadap perilaku petani terhadap hasil panen.

Variabel bebas $(\mathrm{X})$ atau faktor-faktor yang berpengaruh terhadap keputusan petani lada putih terhadap hasil panen di Kecamatan Simpang Teritip pada tingkat 0,010 atau dengan tingkat kepercayaan 90 persen adalah jumlah produksi, sedangkan persepsi harga dan kebutuhan konsumsi berpengaruh pada tingkat 0,05 atau dengan tingkat kepercayaan 95 persen. Dari hasil uji statistik didapat nilai signifikansi untuk variabel jumlah produksi, persepsi harga, dan kebutuhan konsumsi yaitu untuk variabel jumlah produksi sebesar 0,077 , variabel persepsi harga sebesar 0,01, dan variabel kebutuhan konsumsi sebesar 0,033 nilai lebih besar taraf uji 0,05. Dapat dibuat suatu persamaan regresi penduga yaitu:

$\ln =0,813-0,007$ jumlah produksi -4.170 persepsi harga +2.526 kebutuhan konsumsi

Dari data di atas dapat diketahui bahwa dari ketiga kategori yang berpengaruh terhadap keputusan petani lada putih terhadap hasil panen, dapat dianalisis beberapa hal sebagai berikut.

Jumlah produksi. Nilai koefisien regresi untuk jumlah produksi adalah sebesar $-0,007$. Dengan melihat koefisien regresi tersebut, maka jika jumlah produksi yang dihasilkan petani naik sebesar 1 unit, secara rata-rata nilainya akan turun sebesar 0,007 . Hal tersebut menunjukkan adanya hubungan yang negatif antara jumlah produksi lada putih dengan keputusan petani terhadap hasil panen. Artinya semakin tinggi atau banyak jumlah produksi yang dihasilkan petani lada putih, maka keputusan petani cenderung untuk melakukan tunda jual hasil panennya. Odds ratio (rasio peluang yang tidak terjadi) merupakan indikator kecenderungan seseorang untuk melakukan kegiatan langsung jual dan tunda jual hasil panen lada putih. Nilai odds ratio untuk variabel jumlah produksi 0,993. Nilai tersebut menunjukkan bahwa jika jumlah produksi lada putih tinggi atau banyak akan memiliki probabilitas yang lebih kecil untuk langsung jual hasil panennya, yakni sebesar 99,3 persen dibandingkan dengan petani yang jumlah produksinya rendah atau sedikit.

Persepsi Harga. Nilai koefisien regresi untuk persepsi harga adalah sebesar - 4.170. Dengan melihat koefisien regresi tersebut,maka jika persepsi petani akan harga lada putih tinggi 1 unit, secara rata-rata nilainya akan turun sebesar 4.170 unit. Hal tersebut menunjukkan adanya hubungan yang negatif antara persepsi harga tinggi dengan keputusan petani terhadap hasil panen. Artinya semakin tinggi persepsi petani akan harga lada putih, maka perilaku petani cenderung untuk melakukan tunda jual hasil panennya. Nilai odds ratio untuk variabel persepsi harga 0,015. Nilai tersebut menunjukkan bahwa 
perilaku petani yang mempunyai persepsi harga lada putih tinggi akan memiliki probabilitas yang lebih kecil untuk menunda jual hasil panennya, yakni sebesar 0,15 persen dibandingkan dengan petani yang memiliki persepsi harga rendah.

Kebutuhan Konsumsi. Nilai koefisien regresi untuk kebutuhan konsumsi adalah sebesar 2.526. Dengan melihat koefisien regresi tersebut, maka jika kebutuhan konsumsi petani naik 1 unit, secara rata-rata nilainya akan naik sekitar 2.526 unit. Hal tersebut menunjukkan adanya hubungan yang positif antara jumlah produksi lada putih dengan keputusan petani terhadap hasil panen. Artinya semakin tinggi kebutuhan konsumsi petani lada putih, maka perilaku petani cenderung untuk langsung menjual hasil panennya. Nilai odds ratio untuk variabel kebutuhan konsumsi 12,499. Nilai tersebut menunjukkan bahwa perilaku petani yang mempunyai kebutuhan konsumsi yang tinggi akan memiliki probabilitas yang lebih besar untuk langsung jual hasil panennya, yakni sebesar 100 persen dibandingkan dengan petani yang kebutuhan konsumsinya rendah.

KESIMPULAN DAN SARAN

Sikap petani lada putih terhadap hasil panen yang termasuk pada kelompok petani kaya kecenderungannya melakukan tunda jual. Sedangkan pada kelompok petani kecil kecenderungannya sebanyak 56,7 persen petani responden yang langsung jual hasil panennya dan 43,3 persen petani responden yang melakukan tunda jual hasil panennya, Faktor yang mempengaruhi keputusan petani lada putih terhadap hasil panen yaitu variabel jumlah produksi persepsi harga, dan kebutuhan konsumsi.

Mengingat hasil panen lada yang diperoleh petani setiap tahun sekali, diharapkan kepada petani dapat mengembangkan dan mempertahankan tanaman lain seperti karet atau sawit dalam membantu memenuhi kebutuhan hidup sehari-hari petani. Dikarenakan harga lada putih berfluktuasi diharapkan intervensi pemerintah daerah dalam meningkatkan (added value) nilai tambah komoditi lada putih

\section{DAFTAR PUSTAKA}

Arbi, M. 2011. Faktor-faktor yang mempengaruhi petani melakukan tunda jual di Kecamatan Sanden Kabupaten Bantul. Jurnal Staf Pengajar Fakultas Pertanian Universitas Sriwijaya.

Badan Pengelolaan, Pengembangan dan Pemasaran Lada
(BP3L), 2010. Buku Prasyarat Indikasi Geografis. Bangka Belitun: BP3L

Badan Pengelolaan, Pengembangan dan Pemasaran Lada (BP3L), 2015. Data Ekspor-Impor Lada Putih di Provinsi Bangka Belitung. Bangka Belitung: BP3L

Dinas Pertanian, Perkebunan dan Peternakan. 2014.

Statistik Perkebunan Tahun 2015. Kabupaten Bangka

Barat

Dinas Pertanian, Perkebunan dan Peternakan. 2014.

Statistik Perkebunan Tahun 2015. Provinsi Kepulauan

Bangka Belitung

Ghozali, I. 2006. Analisis Multivariate Lanjutan dengan

Program SPSS. Semarang: Badan Penerbit Universitas

Diponegoro.

Hendayana, R. 2012. Penerapan Metode Regresi Logistik dalam Menganalisis Adopsi Teknologi Pertanian.

Makalah Balai Besar Pengkajian dan Pengembangan

Teknologi Pertanian.

Hosmer, D. W dan W. Lemeshow. 1989. Applied Logistic Regression. New York

Oktaviandi, D. 2009. Perubahan Sistem Pasar Lada Putih di Kepulauan Bangka Belitung. Tesis, Program Pascasarjana, Institut Teknologi Bandung, Bandung.

Mawarnita, C. 2013. Analisis Kelayakan Usaha Lada (Piper Nigrum L.) di Desa Kundi Kecamatan Simpang Teritip Kabupaten Bangka Barat. Skripsi, Departemen Agribisnis, Institut Pertanian Bogor.

Mubyarto. 1973. Pengantar Ekonomi Pertanian. Jakarta: Lembaga Penelitian, Pendidikan dan Penerangan Ekonomi \& Sosial.

Supranto, J. 2004. Ekonometri. Buku Kedua. Jakarta: Ghalia Indonesia.

Sriati, H. dan Hutasoit. 2007. Perilaku petani dalam pemasaran hasil kakao dan hubungannya dengan pendapatan. Jurnal Fakultas Pertanian, Universitas Sriwijaya. Tersedia pada: eprints.unsri.ac.id. [diakses pada tanggal 6 Oktober 2014] 